S E L F - O R G A N I Z A T I O N

IN B IOLOGICA L S Y S TEMS 
PRINCETON STUDIES IN COMPLEXITY

EDITORS

Philip W. Anderson (Princeton University)

Joshua M. Epstein (The Brookings Institution)

Duncan K. Foley (Barnard College)

Simon A. Levin (Princeton University)

Martin A. Nowak (Harvard University)

TitLes IN THE SeRIES

Lars-Erik Cederman, Emergent Actors in World Politics:

How States and Nations Develop and Dissolve

Robert Axelrod, The Complexity of Cooperation: Agent-Based Models of Competition and Collaboration

Peter S. Albin, Barriers and Bounds to Rationality: Essays on Economic Complexity and Dynamics in Interactive Systems.

Edited and with an introduction by Duncan K. Foley

Duncan J. Watts, Small Worlds: The Dynamics of Networks between Order and Randomness

Scott Camazine, Jean-Louis Deneubourg, Nigel R. Franks, James Sneyd, Guy Theraulaz, Eric Bonabeau, Self-Organization in Biological Systems 


\section{Self-Organization in Biological Systems}

SCOTT CAMAZINE

J E A N - L O U IS D E N E U B O UR G N I G E L R. FRA N KS

J A M E S S N E Y D

G U Y T H E R A U L A Z

E R I C B O N A B E A U

ORIGINAL LINE DRAWINGS BY WILLIAM RISTINE AND MARY ELLEN DIDION STARLOGO PROGRAMMING BY WILLIAM THIES

PRINCETON UNIVERSITY PRESS

PRINCETON AND OXFORD 
Copyright (C) 2001 by Princeton University Press

Published by Princeton University Press, 41 William Street, Princeton, New Jersey 08540

In the United Kingdom: Princeton University Press, 3 Market Place, Woodstock,

Oxfordshire OX20 1SY

All Rights Reserved

Second printing, and first paperback printing, 2003

Paperback ISBN 0-691-11624-5

The Library of Congress has cataloged the cloth edition of this book as follows

Self-organization in biological systems / Scott Camazine ... [et al.].

p. cm. - (Princeton studies in complexity)

Includes bibliographical references (p.).

ISBN 0-691-01211-3 (cloth : alk. paper)

1. Biological systems. 2. Self-organizing systems. I. Camazine, Scott. II. Series.

QH313.S477 2001

570 '.1'1- dc21

00-045329

British Library Cataloging-in-Publication Data is available

This book has been composed in Times Roman

Printed on acid-free paper. $\infty$

www.pupress.princeton.edu

Printed in the United States of America

1098

ISBN-13: 978-0-691-11624-2

ISBN-10: 0-691-11624-5 